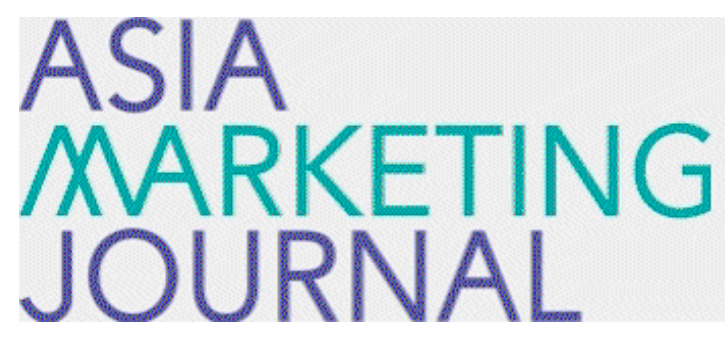

ASIA MARKETING JOURNAL

Volume 14 | Issue 3

Article 9

10-30-2012

\title{
Brand Concept Elaboration Strategy for an Extended Brand
}

Seung Woo Chun

Chang Jo Yoo

Sukek Yu Lee

Lee

Follow this and additional works at: https://amj.kma.re.kr/journal

Part of the Marketing Commons

\section{Recommended Citation}

Chun, Seung Woo; Yoo, Chang Jo; Lee, Sukek Yu; and Lee (2012) "Brand Concept Elaboration Strategy for an Extended Brand," Asia Marketing Journal: Vol. 14 : Iss. 3 , Article 9.

Available at: https://doi.org/10.53728/2765-6500.1494

This Article is brought to you for free and open access by Asia Marketing Journal. It has been accepted for inclusion in Asia Marketing Journal by an authorized editor of Asia Marketing Journal. 


\title{
Brand Concept Elaboration Strategy for an Extended Brand: a Case Study for KB Kookmin Card
}

\author{
Seungwoo Chun* \\ Changjo Yoo** \\ Sukekyu Lee*** \\ Seon Min Lee ${ }^{* * * *}$
}

KB Kookmin Card has separated as an independent corporation from KB Kookmin Bank Credit Card Business Group on March, 2011. Ever since, KB Kookmin Card worked to build its own brand identity. The strategic preparation and conscientious implementations made KB Kookmin Card position in consumer's mind with a strong and unique brand image. Its new brand image was rooted in the inherited strengths of reliable and sincere image. However, it faced the challenge to compete in credit card industry in which most competitors had an advanced and sophisticated image. The strengths of KB Kookmin Card were also at the same time their limitations. KB Kookmin Card took a strategy that strengthened the strengths and improved the weaknesses. It focused on the core competence of being a people's sincere life supporter that helps people make savings from everyday events to make a good sum rather than being a lump sum benefit. The brand introduction strategy was implemented in 2011. The implementation focused on the activities that made internal as well as external customers be aware of the brand. Communication programs using a variety of media were executed to attain this goal. In 2012, second phase communication programs were introduced to elaborate the newly established brand image. It introduced many extended products as well as accessory programs which targeted the segments. Also, various CSR activities in many social domains helped consumers and the public to consider KB Kookmin Card an authentic, caring, trustworthy, and consistently-developing supporter in their everyday lives.

Key words: brand extension strategy, brand equity, brand concept introduction strategy, brand concept elaboration strategy, functional brand concept, emotional brand concept, corporate social responsibility, consumer relationship management

\footnotetext{
* Associate Professor, Dongguk University(schun5@dongguk,edu), Corresponding author

** Professor, Dongguk University

*** Professor. SungKyunKwan University

**** Ph.D. Candidate, Korea University
} 


\section{Introduction}

In March 2011, KB Kookmin Card spun off from KB Kookmin Bank credit card business group and separated as an independent corporation. KB Kookmin Card carefully prepared to become independent from its mother corporation since 2008. KB Kookmin Card deliberately analyzed the established brand equity. understood its strength and weaknesses, and revamped the brand value to build the successful and unique KB Kookmin Card brand identity in the competitive credit card industry.

The credit card market has been expanding exponentially and, accordingly, encountered severe competition. Credit card usage rate as a payment instrument took $57 \%$ share of total private consumption expenditure. Individual credit card usage number has increased from 2.5 billion in 2005 to 5.5 billion transactions per year in 2010 increasing by 3 billion in merely 5 years. The total size of credit card market was 63.6 trillion won in late 1998 and grew to be the 5th largest market worldwide with 493.8 trillion won by late 2010 .

There are two major noticeable changes in the credit card market. First, credit card is threatening and gradually replacing cash as a major payment medium. This phenomenon is expected to grow in the future due to the in- crease in credit card usages that the environment or situations calls. The second change in the market is that the mobile card usages have dramatically increased due to technological advancements. An analyst describes this phenomenon as the "smart big bang" indicating the beginning of a smart life era. Mobile cards, a credit card on a cell phone platform, is expected to evolve to a smart wallet and to become a $\$ 1,130$ billion dollar market in 2014 .

There are 8 major competitors in the national market. 5 competitors such as Hana SK, KB Kookmin, Shinhan, BC, and Industrial Bank of Korea are based on financial institutions and 3 of which - Samsung. Hyundai, and Lotte card - are based on manufacturing institutions. Out of these competitors, Shinhan Card is the market leader with $23.9 \%$ market share and KB Kookmin (14.8\%), Hyundai (13.4\%), and Samsung Card (13.6\%) are competing to take the solid No.2 position in the market. ${ }^{1)}$

In spite of being a late-mover in the very competitive industry, KB Kookmin Card's market share recorded $2^{\text {nd }}$ place. It has harvested the result with a deliberate brand communication strategy and implementations. Now, the task left for KB Kookmin Card is to elaborate its established brand identity and transform this identity into a long-term customer relationship management.

1) The numbers in the parentheses were 2011 accumulated data provided by KB Kookmin Card. 


\section{Steps for Building KB Kookmin Card Brand Equity}

While separating from KB Kookmin Bank, KB Kookmin Card decided to take on the brand assets of the banking business. KB Kookmin Card predicted that KB Kookmin Bank's long 1 history in the banking business and strong relationship with its consumers would be helpful for KB Kookmin Card, as a new brand and late mover in the credit card industry.

However, there were some problems of taking on the mother corporation brand image: its brand image was reliable and trustworthy, but at the same time, old. The first step in building brand equity was solving this dilemma.

\subsection{Brand Awareness}

One advantage of keeping the corporate brand name is its awareness in the customer's mind. KB Kookmin Card decided to keep and inherit the corporate brand name and the brand image. However, taking on the KB Kookmin brand name had pros and cons. It is evident that the $\mathrm{KB}$ Kookmin brand is a valuable asset due to its long history and broad understanding about the people's financial life. This fact is demonstrated in that $34 \%$ of $\mathrm{KB}$ Kookmin Bank's customers have been loyal for over 10 years. On the other hand, this very asset also entails an image far from being high-tech or innovative.

Aware of both the pros and cons, the $\mathrm{KB}$ Kookmin Card brand team decided to pursue a strategy that strengthens the advantages as well as compromises the disadvantages rather than only focusing on strengthening its disadvantages. Through focus group interviews and expert depth interviews, KB Kookmin Card has revamped its brand equity which can be summarized with three major characteristics: a broad understanding of the people's everyday needs obtained from its long history of close relationships with its customers, a sincere consideration for prosperous life of people rather than focusing on giving considerable benefits to the minority, and a consistent effort on developing technology for actualizing the ideas of consideration.

\subsection{Brand Image}

Based on understanding that $\mathrm{KB}$ Kookmin brand has a considerable amount of public financial service experience, KB Kookmin Card declared its brand identity as "the life designer that gives energy to people's life" in March, 2011. This brand identity was driven by a deliberate analysis on the changes in consumer credit card usage patterns in the industrial environment. In addition, it connotes the willingness of brand image reinterpretation.

The declared brand image indicates the com- 
〈Figure 1〉 Reinterpretation of KB Kookmin Card Equity

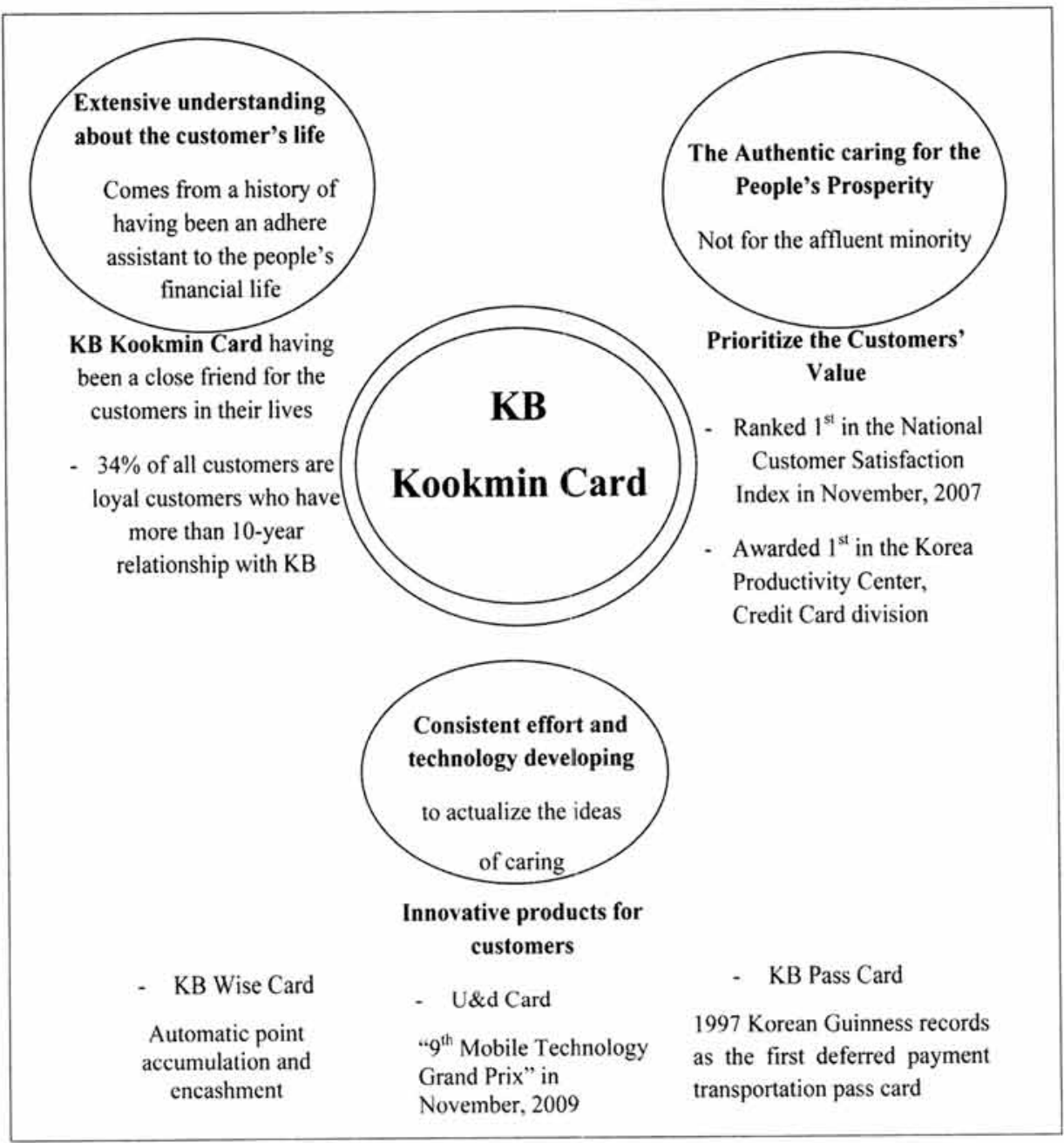

pany's willingness to support consumers' needs in customized ways. It is designed to maximize benefits for each customer in everyday life. For example, the transportation card function provides convenience as well as discounts on everyday commuting. The card also provides automatic payment services for utility bills, apartment maintenance fee, communication expenses, etc. Furthermore, credit card users are able to get additional discounts for family trips, amusement park visits, fitness centers and grocery shopping during weekends.

These practices was intended to make consumers have certain images about KB Kookmin Card. KB Kookmin Card elaborately designed to embed three main brand images: consideration, sincerity, and endeavor. Consideration implies KB Kookmin Card always cares to satisfy con- 
〈Figure 2〉 Brand Identity Pyramid

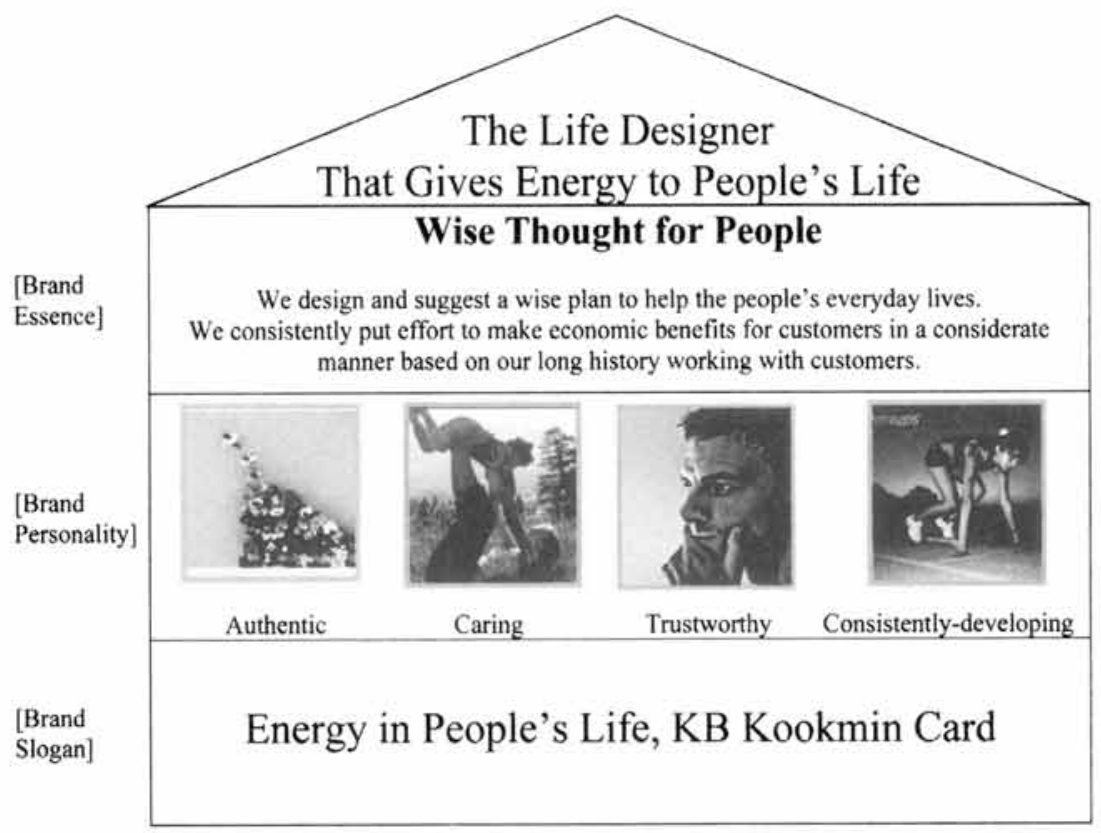

sumers' needs and wants of everyday life and prepares thoughtful services a step ahead. Sincerity implies KB Kookmin Card consistently does its best to serve customers' daily routine. Endeavor expresses the promise of KB Kookmin Card which continuously conducts studies on consumer's unsought needs and finds a way to transform KB Kookmin Card's considerate services into a form of energy in consumers everyday life.

\section{Brand Concept Introduction Strategy and Implementations}

As a brand introduction strategy, KB Kookmin
Card took a position in compatible with its original brand identity. It took a bilateral approach directed at both internal as well as external customers. The reason for targeting both internal and external customers was to keep a coherent brand image. The activities targeted to make external customers become aware of the brand and the internal activities to make the employees be educated about the brand were implemented simultaneously. Once the strong brand image was established and shared among both internal and external members, KB Kookmin Card expected a higher chance of bringing in new customers and developing brand loyalty among its existing consumers. 


\subsection{External Activities for Brand Awareness Improvement}

\subsubsection{Mass Communication}

KB Kookmin Card decided to use mass communication to let people know the newly branded KB Kookmin Card. Their campaign emphasized on the KB Kookmin Card's role of cheering the nation, giving energy to people's everyday life and its substantial economic benefits. In the early pre-launching stage, a teaser advertising was used in communication and its message emphasized that the card gives various financial benefits useful for everyday life. Especially, the pre-launching campaign used the catch phrase "Cheer up! XX yearolds" and showed contrasting images between a famous person and an average person of the same age. For example, it showed Queen Victoria of England becoming a queen at the age of 18 years olds and an ordinary 18-yearold in Korea who struggles with the severe competition of college entrance exam.

After KB Kookmin Card formally launched in March, 2011, it started the main advertising campaign. The main campaign stared a famous celebrity "LEE Seung Gi" introducing the actual products "KB Kookmin Wise Home Card" and the affiliated store brands "DC Shop" and "Star Shop." The advertising described some slice-of-life episodes which depict the economic benefits a customer could obtain by using the card as a means for daily basis payments shopping, apartment maintenance payment, children's private institution tuition and extraactivities fee.

\subsubsection{Superstar K3 \& K4 Sponsorship}

By sponsoring a famous cable network audition program "Superstar K" for two consecutive years, the KB Kookmin Card effectively implemented its goal of communicating with the young generation. KB Kookmin Card elegantly arranged its logo and reminders to be exposed to the audiences during the show. Throughout the airtime, its brand color yellow was exposed in a uniform manner on show props: waiting tents provided for the audition participants, cheering tools, KB Kookmin RockStar Check Card, a jury table, team assignment studio settings, admission tickets shaped after a card. Top 10 cards, etc. KB introduced a special limited-edition check cards each year to celebrate its sponsorship. In 2011, the first year of sponsorship, KB Kookmin Card released a limited number of the special check cards targeting the young - Only 3,333 KB Kookmin Nori Check Cards were issued and sold out within only 35 business days. The 2012 version of $\mathrm{KB}$ Kookmin Be*Twin Check Cards was also introduced.

The effect of first year sponsorship, measured in economic value, recorded more than 15 billion won in direct advertisement effect 
〈Figure 3〉 Superstar K3 \& K4 Sponsorship

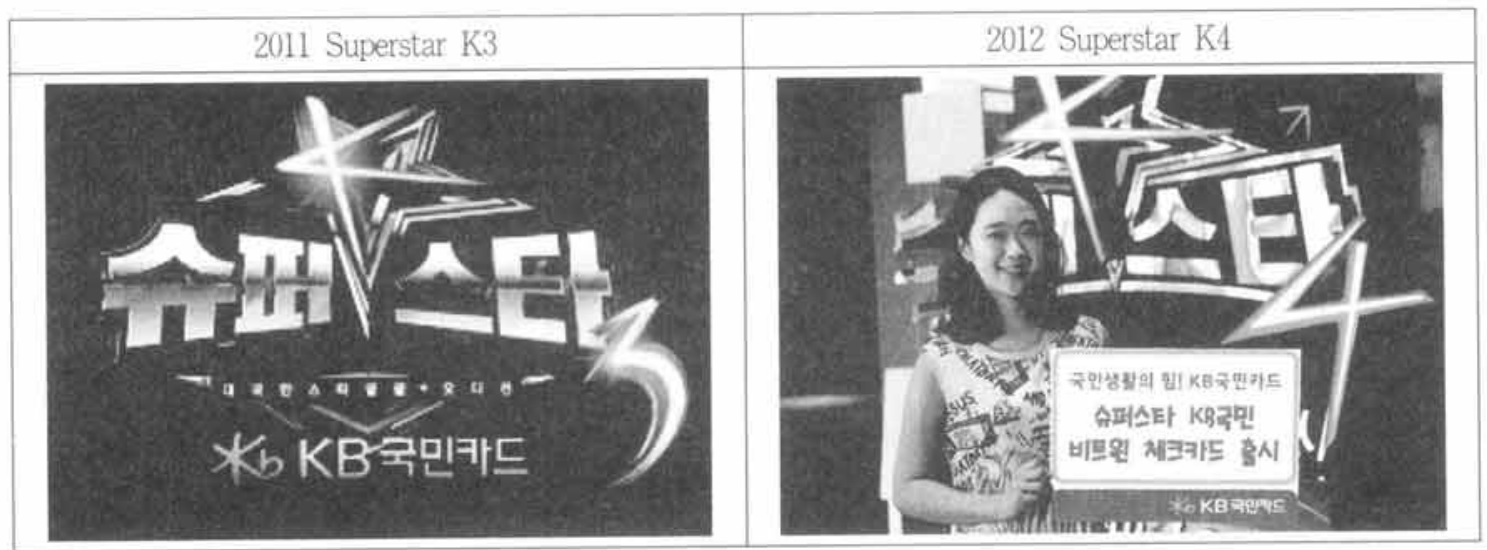

with only a 3 billion won investments. It was a more efficient sponsorship than the previous sponsor Coca-Cola who invested 5 billion won. The most valuable record was that it brought the young's interest on the KB Kookmin brand and renewed the KB Kookmin Card's brand image from old and dull to joyful and vibrant.

\subsection{Internal Stakeholder Participation for Brand Equity}

KB Kookmin Card prepared various communication programs focusing on its internal stakeholders. The activities were carefully designed for internal members to have a thorough knowledge of the new brand identity meaning and to be prepared for subsequent practices.

In June 2011, KB Kookmin Card Brand Identity (BI) was proclaimed and the ceremony was broadcasted to the headquarters as well as all of its branches. In addition, several BI related activities were held. There was a photography contest in which it awarded the employee with the best images that represented the theme of 4 types of brand personality (Authentic, Caring. Trustworthy, and Consistentlydeveloping). While participating in the ceremonies and other activities, employees can foster the interest and understanding about a background and a spirit of $\mathrm{BI}$.

In addition, a brand story was created and exposed continuously to every employee. A brand story was made in an e-book format which was shown on the elevator, played as an animation on office broadcast program, and linked as a banner on the main page of intranet home page. Also, the slogan of "the life designer that gives energy to people's life" was printed on tumblers and note-pads and distributed to the employees.

Being consistently exposed to the brand communication, employees and executives learned correctly the knowledge of the Corporate Identity Graphic Standards. The executives and 
〈Figure 4〉 Internal and External Activities for Brand Introduction Strategy

\begin{tabular}{|c|c|c|}
\hline \multicolumn{3}{|c|}{ EXTERNAL CUSTOMER BRAND COMMUNICATION ACTIVITIES } \\
\hline $\begin{array}{c}\text { Mass Media Advertising and } \\
\text { Sponsorship }\end{array}$ & Customer Campaign \\
\hline
\end{tabular}

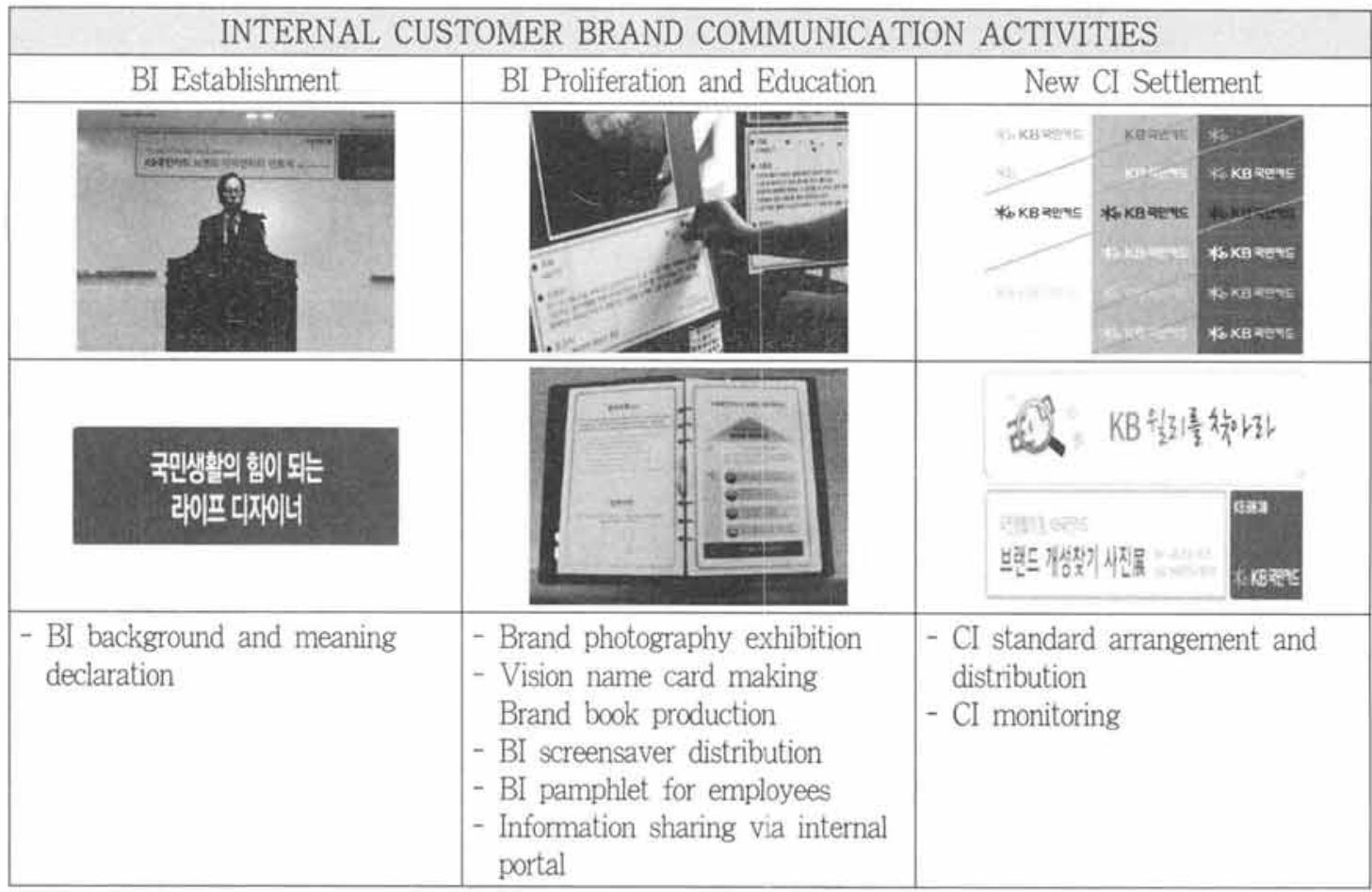

160 ASIA MARKETING JOURNAL Vol. 14 №.03 October 2012 
employees were encouraged to join a competition which claims to parody the famous game "Where's Wally?" The goal of this activity was to find errors on brand marks, typos, misleading information, etc. This activity provided internal members an opportunity to have fun while learning the new brand identity and its related information correctly.

\section{Brand Concept Elaboration Strategy and Implications}

KB Kookmin Card not only successfully bridges the advantages of well-established corporate brand image but also creates strong and unique image to the new extended credit and debit card brand through 1-year brand introduction stage from March, 2011. In early 2012, KB Kookmin Card brand management team decided that it was an appropriate time to start an elaboration strategy to strengthen their brand image to build stronger brand equity.

KB Kookmin Card brand images were elaborated through a two-way approach: functional and emotional concept elaborations. First, KB Kookmin Card's functional concept included financial benefits, multiple partnership \& optional services and additional economic benefits. It also provided an emotional concept which comes in forms of reliability, friendliness and representative of its customers. However, the brand management team needed to develop a separate brand elaboration strategy of each type of brand concepts and, more importantly. a way to incorporate each strategy in a long-term perspective - how to manage the customer relationship.

\subsection{Functional Brand Concept Elaboration Strategy}

To elaborate on the functional brand concept. KB Kookmin Card diversified card products to satisfy the various needs of segmented consumers. KB Kookmin Card identified that consumers have two types of very paradoxical needs. Consumers wanted a unified card that encompasses multiple benefits at once. but at the same time, required a very carefully segmented card to represent their individual needs.

In order to satisfy both needs, KB Kookmin Card introduced a general benefit card such as KB Kookmin Wise Card as well as 6 other specialized benefit cards. KB Kookmin Wise Card represents its total benefits in its name. with the acronym for Wise, Innovative. Suocessful, and Easy. It encompasses all of promises in life. shopping/dining, entertainment, automobile, education and medical services. In line with the generalized services, KB Kookmin Card also provides specialized services for each segment of consumers who require more sophisticated benefits in a certain area. KB Kookmin Card divided consumers needs into 6 specialized 
types - life, shopping/ dining, entertainment, automobile/gas, education and medical services. These 6 separate card services emphasized special benefits in each aspect of financial life. It also added more credit cards in product lines that provide speialized benefits in alliance with mobile, airline, government support for women and childcare, and community services. $\mathrm{KB}$ Kookmin Card also provides a tool on its Web page for consumers to search for a customized card that meets their specific financial benefit needs.

\subsection{Emotional Brand Concept Elaboration Strategy}

The most typical strategy used to elaborate the emotional brand concept is to maintain the stimulation and preventing the satiation with the brand. The best tactic is to introduce the accessory and extended products. KB Kookmin Card has established a reliable, advanced, young and passionate image through marketing communication effort that occurred during its brand concept introduction stage. So, the next task for KB Kookmin Card was to develop various accessory products to elaborate on these brand images.

KB Kookmin Card introduced new communication programs through which the brand shares exciting experiences with the consumers. It declared the year 2012 as a starting year for the programs' implementations. KB Kookmin Card introduced new activity programs which gave consumers an opportunity to experience the essence of "life energy." Two main programs were designed to facilitate and share the consumers' experience and emotions about the brand.

First, KB introduced the camping theme campaign called "Endor-ping (엔돌핑)." Endorping

〈Figure 5〉 2012 "Endorping" campaign

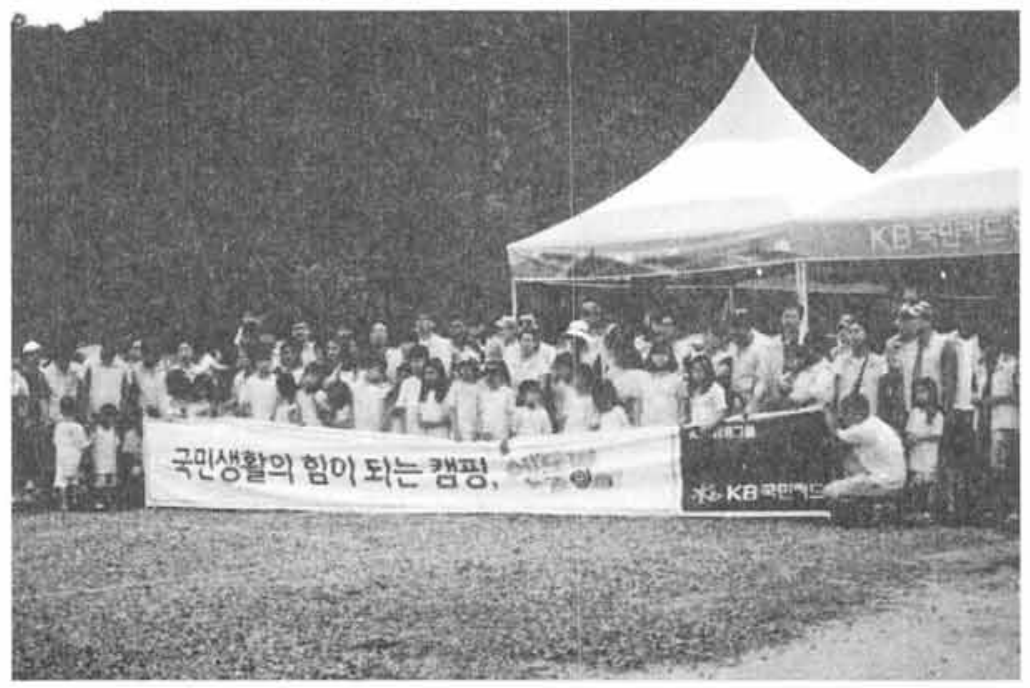

162 ASIA MARKETING JOURNAL Vol. 14 No. 03 October 2012 
is a neologism that combines two words. "endorphin" and "camping," which provides segmentspecific healing opportunity at camping sites. The purpose of this program was two-sided. It provided current as well as potential customers an energizing opportunity to experience comfortable rest and five-sense healing through overnight camping. It also offered the convenient facilities such as restroom to support camping sites to make a healthy and pleasant camping culture.

Joining this program, consumers had time to recharge themselves in nature. KB Kookmin Card provided all the equipment needed for camping. meals and entertainment programs for an overnight itinerary. "Endorping" provided 4 types of camping programs, each of which elaborately targeted the different segments: family, women, friends, and college students.

Second program called "Dreaming Adman(꿈
꾸는 광고인)" was designed to elicit a two-way communication through consumer participation in the brand communication. The purpose of "Dreaming Adman" was to elaborate on the brand awareness in a way of supporting consumer's viral communication through Internet, mobile and new media. It was a more suitable program to efficiently target the young generation. College students and business people who participated in "Dreaming Adman" provided new and appealing ideas about KB Kookmin Card advertisements and the ideas were collected for an idea bank contest. The ideas were actualized for a formal advertisement airing in cable networks. The winners of the contest were qualified to attend a 1-year marketing education program, provided in collaboration of the KB Kookmin Card and an advertising agency. This program included a marketing education.

〈Figure 6) Actual KB Kookmin Card Advertising Campaign in 2012 Executed from the Idea Awarded at Dreaming Adman Contest
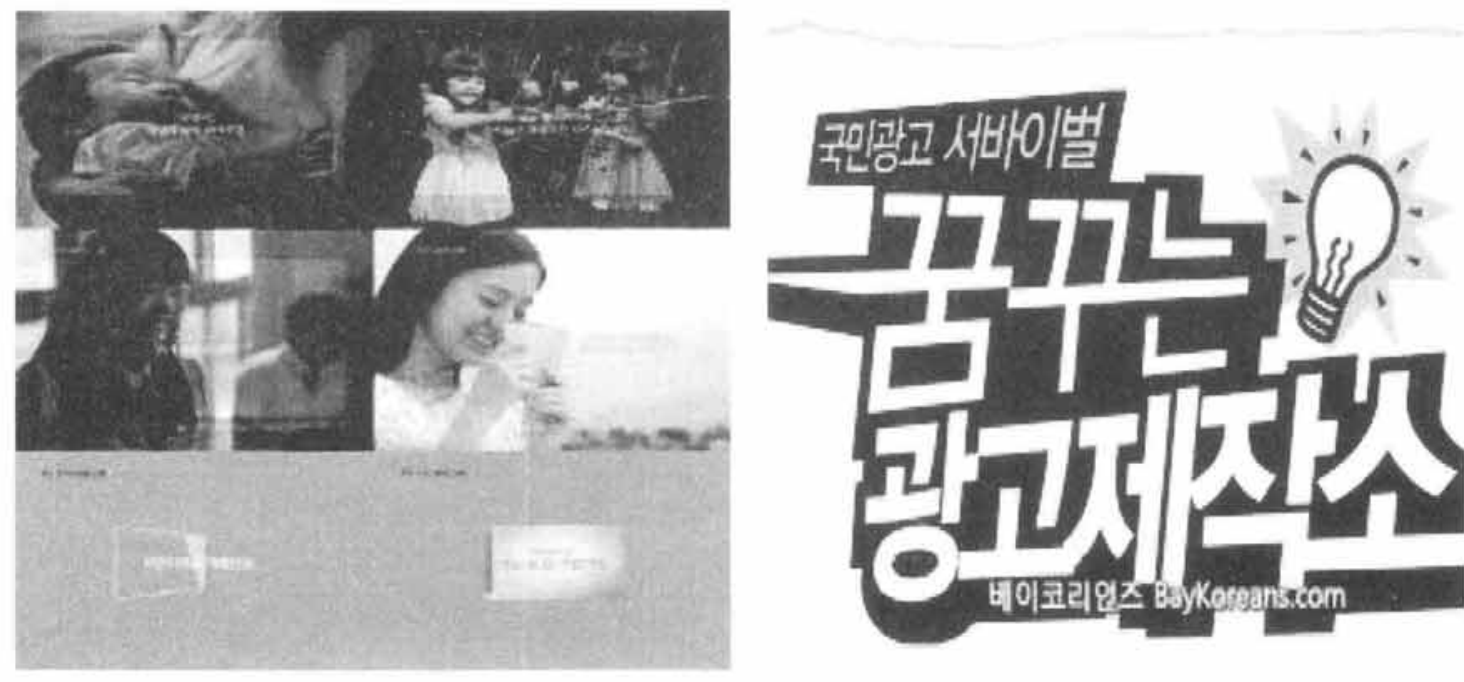
International Advertising Festival tour, and an employment opportunity. It was a win-win program which provided $\mathrm{KB}$ Kookmin Card unconventional ideas for its advertisement and in return provided employment opportunities to participants and society at large.

KB Kookmin Card, along with a cable channel CJ E\&M, launched a TV show called "Dreaming Ad Production" on Mnet cable network. The show borrowed a survival audition format for an advertising competition. A total of 10 teams joined the competition and the winning team received a prize of $1,000,000,000$ won. In addition, the winning idea was actually used for KB Kookmin Card advertisement campaign during 2012.

\subsection{Connecting Brand Concept Elaboration Strategy with Customer Relationship Management}

To elaborate on the brand concept, KB Kookmin Card developed a variety of accessory and extended products. When developing these products, the aim of the brand management team was to strengthen the relationship with the current consumers by using an elaborated brand concept. Therefore, all of the brand concept elaboration programs were carefully designed to meet the dual purposes: to elaborate the established brand concept in consumers' mind and to strengthen the relationship with them.

KB Kookmin Card selected three targets to show its benevolence: the current customers. the potential customers and the public. KB Kookmin Card carefully designed and communicated its major products and promotions relevant to the brand identity to current consumers. In addition, KB Kookmin Card approached potential consumers to build brand awareness and favorable attitude. It exposed its brand as a main sponsor of the famous cable TV show "Superstar K" as well as professional sports team such as baseball team "Doosan Bears" and professional Korea Basketball League. While being the major sponsor of "Superstar K," an audition program on Mnet cable network, KB Kookmin Card leveraged its advantage to a brand song campaign called "Happy Day." The winner of Superstar K sang the KB Kookmin Card brand song and the film was uploaded on YouTube for others to enjoy and voluntarily participate in the campaign. Utilizing new media was the best way to reach and encourage the youngsters' voluntary participation in the campaign.

KB Kookmin Card developed a new type of corporate social responsibility programs through its own branded public interest program which differentiated itself from other types of socially responsible activities, "Wish Together" program organizes a supporting community to make every participants and their neighbors wishes come true. "Wish Together" program is divided into two parts: "Wish Star" and "Wish Leader." "Wish Star" helped the participant's wish rea- 


\section{〈Figure 7〉 External Customer-Oriented Communication Activities}

- All communication activities have unfolded to disperse the young and dynamic new brand image of KB Kookmin Card. The opportunities of experiencing the energy in people s life KB Kookmin Card offers were included.

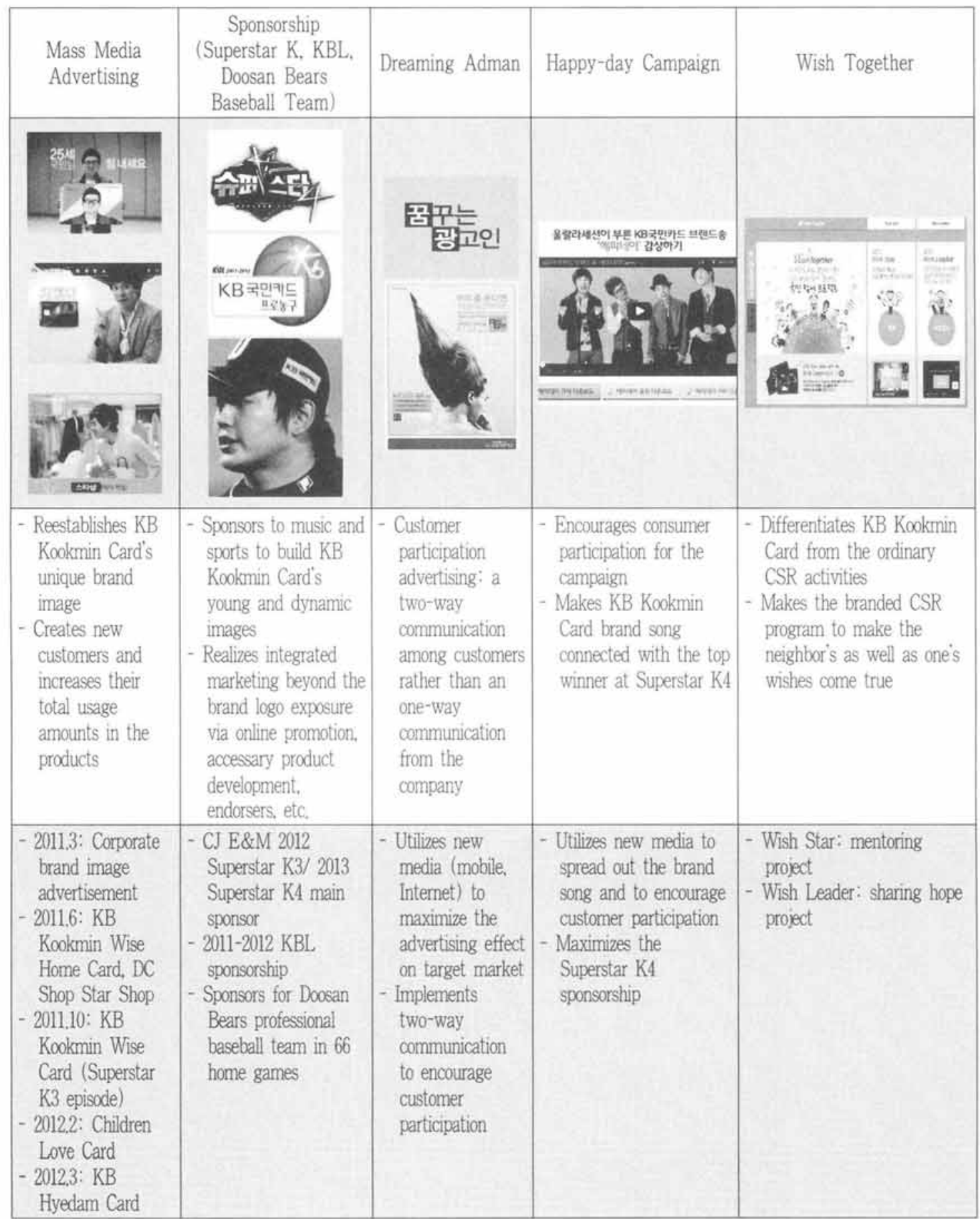


lization and "Wish Leader" helped a neighbor's wish come true. "Wish Star" provided participants passionate about various areas such as photograph, cooking, film, or sports an opportunity to experience mentoring services provided by the experts in the given areas. Meanwhile, KB Kookmin Card supported 2,000,000 won to solve difficulties of the needed through the "Wish Leader" program.

\section{Conclusion}

The measurement of the brand elaboration strategy is as follows.

First, the overall brand recognition was noticeably enhanced. The results were inspiring in that KB Kookmin brand's top of mind awareness index increased $5.3 \%$. In addition, an unaided awareness rate has increased by $2 \%$. These figures denote the possibility of $\mathrm{KB}$ Kookmin Card becoming an exemplar brand of its category in the near future. As an evidence of the prediction, the market share of KB Kookmin Card ranked second in only 1 year which remarked an exponential growth of brand power in highly competitive credit/debit card industry. In particular, KB Kookmin Check Card ranked $1^{\text {st }}$ in the industry according to the KCSI index.

Second, the brand image reconstruction effect was noteworthy. The specific effort devoted to each domain of functional as well as emotional brand concept elaboration paid off. According to an online research, conducted and responded by 300 Seoul and Gyunggido residents in late 2011, three components of the functional brand concept - financial benefits, affiliate/additional services, and discount benefits were said to have increased $2.3 \%, 2.0 \%$ and $6.0 \%$ respectively. In addition, three components of the emotional brand concept - reliable, advanced, young and passionate - showed an amplified figure of $1.6 \%$ for the first and $3.6 \%$ for the last. The second component of the emotional brand concept has not changed after the elaboration activities. The advanced image might not be an appropriate measure since the brand concept elaboration efforts mostly emphasized on $\mathrm{KB}$ Kookmin Card's supporting role of energizing up people's everyday lives. People might perceive the advanced image as irrelevant to the campaign. The financial index indicated that $\mathrm{KB}$ Kookmin Card not only successful in establishing a renewed brand concept to the market but also ensured internal stability and competitive advantage as a viable unit. The KB Kookmin Card asset recorded 13,400 billion won in late 2011 which indicates a 1,000 billion won increase since the asset valuation of March, 2011. More importantly, the net profit was 319.8 billion won out of its total asset during the term.

As a result of deliberative and consolidative brand concept strategy, KB Kookmin Card not only successfully extended its brand to the 
〈Figure 8> Measurement of Brand Awareness and Brand Image Elaboration

\begin{tabular}{|c|c|c|c|c|c|c|c|}
\hline \multicolumn{2}{|c|}{ Brand Awareness Index } & \multicolumn{6}{|c|}{ Brand Image Elaboration Index } \\
\hline & 59.361 .31 & $53.0^{543}$ & & & $48.7^{51}$ & & \\
\hline $\begin{array}{l}\text { Top of } \\
\text { Mind }\end{array}$ & $\begin{array}{c}\text { Unaided } \\
\text { Awareness }\end{array}$ & $\begin{array}{c}\text { Financial } \\
\text { Benefits }\end{array}$ & $\begin{array}{l}\text { Affiliated } \\
\text { Additional } \\
\text { Services }\end{array}$ & $\begin{array}{l}\text { Discoumt } \\
\text { Benefits }\end{array}$ & Reliable & Advanced & $\begin{array}{l}\text { Young/ } \\
\text { Passionate }\end{array}$ \\
\hline
\end{tabular}

credit card industry but also established a Discussion Points unique brand concept for $\mathrm{KB}$ Kookmin Card on its own. In terms of total amount spent, $\mathrm{KB}$ Kookmin Check Card marked its solid $1^{\text {st }}$ player position in the market and the credit card also maintained $2^{\text {nd }}$ rank position with approximately a 15\% market share. The current credit card industry divides into one top company. Shinhan Card $(22.5 \%)$, and a group of several companies who are competing for the solid second position. ${ }^{2}$ As a result of its brand concept elaboration effort. KB Kookmin Card, now fully armed with the strong and unique brand image, is standing on the starting line again. Moreover. its strong brand power can act as an engine to move forward to challenge the market leader position in the near future.

1. What were the strengths and weaknesses of the KB Kookmin Card brand extension strategy?

2. Discuss the practices KB Kookmin Card took in its brand introduction and elaboration stages. What are the similarities and differences between the two stages?

3. KB Kookmin Card utilized a two-way approach to elaborate its brand concept. Describe and discuss about the purpose and practices of each approach. If possible, what other approaches should KB Kookmin Card consider taking?

2) The individual market shares of each company (August 2012 Accumulated Data) are 15.9\% (KB Kookmin Card). 13.4\% (Hyundai Card), and $14.4 \%$ (Samsung Card) provided by KB Kookmin Card. 